\title{
What Explains FDI Flows to Latin America? A Pooled Analysis, 1980-2006
}

\author{
Miguel D. Ramirez \\ Department of Economics, Trinity College, Hartford, CT \\ E-mail: miguel.ramirez@trincoll.edu
}

\begin{abstract}
This paper estimates a pooled (fixed-effects) FDI investment function that seeks to identify some of the major economic and institutional determinants of FDI flows to nine major Latin American countries during the 1980-2006 period. First, it develops a conceptual framework of analysis that seeks to identify some of the major economic and institutional determinants of FDI. Second, the paper gives an overview of FDI flows to Latin America during the 1990-2011 period, with particular emphasis on their contribution to the financing of gross capital formation. Third, an empirical model for FDI flows to Latin America is outlined and an economic rationale is provided for the included variables and their expected signs. Fourth, the estimates from a panel regression designed to explain the variation in FDI flows to Latin America during the 1980-2006 period suggests that market size (proxied by real GDP), credit provided by the private banking sector, government expenditures on education, the real exchange rate, and the level of economic freedom have a positive and significant effect. On the other hand, public investment spending, the debt-service ratio, and the volatility of the real exchange rate have a negative and significant effect on FDI flows. The panel unit root tests on the residuals of the relevant panel regressions also suggest that there is a stable, long-term relationship among the included variables; i.e., the selected variables in the reported regressions are cointegrated over the relevant time period. Finally, the paper summarizes the major findings and offers some policy prescriptions for attracting FDI flows to the region and enhancing their positive direct and indirect effects.
\end{abstract}

Keywords: ADF Fisher statistic. Economic Freedom Index (EFI), Foreign Direct Investment (FDI), Latin America, Panel Unit Root Tests, Pedroni Residual Cointegration Test, Pooled Regression, Remittances of FDI profits, and Seemingly Unrelated Regression (SUR).

\section{Introduction}

The abandonment of import substitution industrialization (ISI) in most of the countries of Latin America and the Caribbean during the 1980s and early 1990s led to the adoption of a market-based, outward-oriented strategy of economic growth and development. Along with the wholesale privatization of state-owned industries and the deregulation of financial and labor markets, this market-based strategy has been associated with a dramatic liberalization of trade and the opening of capital markets. Insofar as capital flows are concerned, foreign direct investment (FDI) under the auspices of transnational corporations has become one of the key elements in the process of economic and financial integration of the region. Some indication of the importance of these flows to the region can be surmised from the following figures: net FDI flows to the countries of Latin America and the Caribbean rose dramatically from $\$ 8.4$ billion in 1990 to $\$ 77.2$ billion in 2000 and almost 100 billion in 2008, before falling precipitously to 70 billion during the recessionary years of 2009 and 2010 (see [1]). However, in the wake of the dramatic economic recovery experienced led by South America (particularly Brazil and Argentina) during the 2010-11 period, these net inflows are estimated to have risen sharply to 130 billion in 2011 (see [1]). From a relative standpoint, Latin America's share of FDI flows to developing countries rose from 29 percent in 1995 to an-all time high of 39.5 percent in 2000, before falling to a low of 28.9 percent during the recession year of 2009, and then rebounding, respectively, to 30.5 and 32 percent in 2010 and 2011 ([1]). As discussed below, part of the reason for the fall in the share of FDI flows to the region in recent years can be explained by the Great Recession in the United States in 2008-09 and the completion of major privatizations in industry, banking, and mining in the region (see [1]). The recent resurgence in FDI inflows to the region is led primarily by investments in natural resource endowments and so-called "Greenfield investments" in manufacturing and services, and it remains to be seen whether it can be sustained beyond the immediate future [see [1]: Table B, p. 52]. 
The economic rationale for opening the region's capital markets to both portfolio and FDI flows resides in the belief that foreign capital can help bridge the gap between savings and investment in capital-scarce economies and, particularly in the case of FDI flows, bring modern technology and managerial knowhow that promotes economic growth and encourages the development of financial markets. There is also a growing body of empirical evidence which suggests that FDI flows, as opposed to portfolio investments in the form of short-term bond and equity investments, are less volatile because they involve longer term commitments that often lead to the establishment of foreign subsidiaries as well as the acquisition of existing entities via international mergers (see [2]; [3]; [4]; [5]; and [6]). FDI is often referred to as the "good cholesterol" because, from a macroeconomic standpoint, it is less likely than portfolio investments to leave emerging markets at the first hint of economic trouble as evidenced by their relative stability and growth during the financial and economic crises that have buffeted emerging markets during the 1990s and beyond (see [4]; [2]: Tables 3 and 5; and [6]). Finally, to the degree that FDI flows are directed to the establishment of new enterprises in leading sectors, so-called "Greenfield investments," as opposed to the buying of existing firms via mergers and acquisitions, so-called "Brownfield investments," the economic impact of these flows on long-term regional growth and development is likely to be greater (see [7]; and [8]).

In view of the importance of this topic for the future economic performance of Latin America, this paper estimates a pooled (fixed-effects) FDI investment function that seeks to identify some of the major economic and institutional determinants of FDI flows to nine major Latin American countries during the 1980-2010 period. The paper is organized as follows: First, the paper develops a conceptual framework of analysis that seeks to identify some of the major economic and institutional determinants of FDI. Second, the paper gives an overview of FDI flows to Latin America during the 1990-2010 period, with particular emphasis on their contribution to the financing of gross capital formation. Third, an empirical model for FDI flows to Latin America is outlined and an economic rationale is provided for the included variables and their expected signs. Fourth, the paper reports estimates from a panel regression designed to explain the variation in FDI flows to Latin America during the 1980-2006 period. It also undertakes panel unit root tests on the residuals of the relevant panel regressions to determine whether there is a stable, long-term relationship among the included variables; i.e., it tests whether the selected variables in the reported regressions are cointegrated. Finally, the paper summarizes the major findings and offers some policy prescriptions for attracting FDI flows to the region and enhancing their positive direct and indirect effects.

\section{Conceptual framework}

From a theoretical standpoint, John Dunning ([9]; [10]) has developed one of the most comprehensive explanations of why TNC firms undertake cross-border investments. He argues that TNCs invest abroad when three sets of relative advantages are present. First, the establishment of TNC subsidiaries gives the parent firms exclusive ownership rights over patents, trademarks, commercial secrets and production processes, thereby effectively denying access to both foreign and domestic competitors. Second, they generate for TNC affiliates locational advantages that arise from direct access to growing markets and lower unit labor costs, reduced transportation and communication costs, avoidance of tariffs and non-tariff barriers, and last but not least, direct access to raw materials, low-cost unskilled labor, and intermediate products that are indispensable for the production of certain goods. Michael Mortimore ([11]), building on Dunning's work, argues that the relative importance of location specific determinants depends on TNC motivations for investing, viz., whether FDI is motivated by market-seeking (access to internal and export markets), natural resourceseeking (access to natural resources and low-cost labor) or efficiency-seeking reasons (cost and quality of human resources and physical infrastructure resources).

Third, Dunning points to the advantages TNCs derive from internalizing certain operations because utilizing market mechanisms are relatively more burdensome and costly. For instance, many TNCs would rather establish a subsidiary abroad and assume directly the contractual and administrative costs associated with research, development, production, and marketing of a given product or service, thereby avoiding the transaction costs associated with leasing licenses and securing patents to undertake production or hiring the services of advertizing agencies to market and distribute their products. In this connection, Markusen ([12]) argue that firms choose direct investment rather than licensing primarily because of the non-excludability property of new knowledge capital; viz., it is too costly for TNCs to prevent licensees from "defecting" and copying the new technology at little cost and setting up their own domestic firms in direct competition with the TNCs.

Thus, a fourth and highly important determinant of FDI not entirely emphasized by Dunning is based on strategic considerations. The decision by TNCs to undertake investments abroad for strategic reasons has been greatly facilitated in recent years by the globalization of financial markets which, in turn, has significantly reduced entry barriers associated with large fixed costs. For example, Aliber ([13]) and others contend that large TNCs, with their greater [and cheaper] access to financial capital, have both the ability and the incentive to enter foreign markets to preserve market share and profits which are threatened by other indigenous and foreign firms. For similar strategic and tax reasons, TNCs are able to give the appearance of repatriating a lower profit without reducing their actual profit by manipulating 
intra-firm transfer pricing. For example, TNCs have the incentive to charge high prices for inputs to subsidiaries operating in high-tax countries and charge low prices for the output which these subsidiaries sell back to the parent company. In this manner the TNC is able to attain a number of strategic objectives, viz., it is able to keep its reported profit rate low and thus reduce its overall corporate taxes; it is also likely to avoid bad publicity and potential expropriation via accusations of price gouging from the host country government; and last but not least, it is able to discourage the entry of indigenous firms and foreign firms who perceive incorrectly the profit opportunities available in the market [see [14]; and [15]] .

Fifth, host country determinants also seem to play a very important role in either attracting or discouraging FDI flows to developing countries. For example, countries that exhibit a greater degree of political and macroeconomic stability, the existence of well-defined and enforceable property rights when it comes to the transfer of technology, liberal legislation governing the remittance of profits and dividends, and limited or non-existent local content or export requirements tend, on average, to attract greater flows of FDI. However, from the standpoint of the host country the very factors which act as an incentive for FDI flows in the short run may prove detrimental to long-term economic development if they lead to a net outflow of resources, few backward and forward linkages (an "enclave" facility), the elimination of domestic firms that could have developed into successful enterprises without this premature exposure to competition, and limited transfers of technology and managerial knowhow (see [16]; [17]; and [18]).

The nature and scope of government policies are also a highly important factor in determining whether FDI flows to developing economies such as Chile. For example, FDI is likely to be attracted to countries where governments ensure an adequate provision of economic and social infrastructure in the form of paved roads, ports, airfields, relatively cheap energy supplies, and a well-educated and disciplined work force. In this connection, several investigators have found that the availability of skilled workers and adequate physical infrastructure are important determinants of FDI flows because it enables TNCs to strengthen both their ownership and locational advantages, thus allowing them to expand their market not only in the host country but the region as well (see [19]). In addition, FDI flows are likely to be encouraged by government policies that lead to the establishment of a legal-institutional framework that is conducive to business activity; viz., one that significantly reduces the transactions costs associated with negotiating contracts, improves information about the quality of goods and services, and make sure that the parties to a formal agreement honor their commitments (see North, 1990 [20]; and Yeager, 1998[18]).

Finally, changes in a country's exchange rate policy play a key role in altering its relative attractiveness to net FDI inflows. Not surprisingly, economists are not entirely of one mind when it comes to the optimal exchange rate strategy to pursue. For example, some investigators argue that a policy that keeps the real exchange rate undervalued relative to that of its key investment partners is, ceteris paribus, likely to enhance FDI flows because it artificially reduces the unit costs of the country's factors of production and thus enables investors to make a significantly larger investment in terms of the domestic currency. They also contend that it enhances the profitability of the export-oriented sector which, in turn, attracts FDI flows to them. Therefore, the amount of FDI should increase with a real devaluation of the domestic currency after a reasonable lag (see [21]).

Other researchers contend that a policy that leads to a real appreciation of the domestic currency is likely to encourage FDI inflows because it enhances the foreign currency (dollar) value of the remittances of profits and dividends back to the parent company (see [22]). After all, it is the real rate of return on their initial (dollar) investment that matters to the parent company. In light of the conflicting views in the literature on the impact of the exchange rate on FDI flows, it is best, from a policy standpoint, to pursue a credible strategy that maintains the country's real exchange rate in line with that of its key trading and investment partners.

\section{FDI flows to Latin America during the 1990-2011 period}

Following the debt crisis, net FDI inflows (gross inflows minus outflows) to Latin America and the Caribbean declined in absolute terms during the first half of the 1980s, after which they began to increase steadily during the second half of the 1980s and posted a dramatic surge during the decade of the 1990s. For example, between 1985 and 1990 these flows averaged $\$ 8$ billion on an annual basis, while during the 1991-1999 period alone they averaged $\$ 55.8$ billion, or almost seven times as much [see ECLAC, 2012[23]]. The acceleration in FDI flows during the 1990s was also characterized by an increasing proportion of these funds directed to emerging nations such as China, India, as well as the major countries of Latin America and the Caribbean. For example, net FDI flows to Argentina, Chile, Brazil , Mexico, and Peru averaged close to $\$ 52$ billion during the 1996-2001 period, before falling to $\$ 37$ billion in 2002 , and $\$ 25.7$ billion in 2003 as a result of the relatively mild 2001 U.S. recession. Figure 1 below shows that with the recovery of economic activity in the United States after 2003, FDI flows to the countries of Latin American and the Caribbean resumed at a brisk pace as attested by the rise in net inflows to $\$ 57$ billion in 2005, $\$ 94.2$ billion in 2007, and almost $\$ 100$ billion in 2008, before falling sharply in 2009 in the aftermath of the Great Recession of 2007-09 ([1]). 
Figure 1 below also reveals that the abrupt fall in net FDI flows to Latin America and the Caribbean in 2009 and 2010 was quickly reversed in 2011 when the region, led by Argentina, Brazil, Chile, Mexico, and Peru experienced a sharp inflow of funds as a result of the surprisingly quick economic turnaround in most emerging markets--thanks to aggressive Keynesian style countercyclical policies in countries such as China, India, Brazil, and Argentina-- relative to their developed counterparts in Europe and the United States. According to preliminary figures, the surge in net inflows to the region that began in 2011, attaining an all-time high of \$130 billion, has continued into 2012 and can be traced to relatively higher prices for key primary commodities such as copper, nickel, and petroleum, strong domestic demand in the form of consumption and investment (particularly in Argentina and Brazil), and the high rate of return on investments in the region.

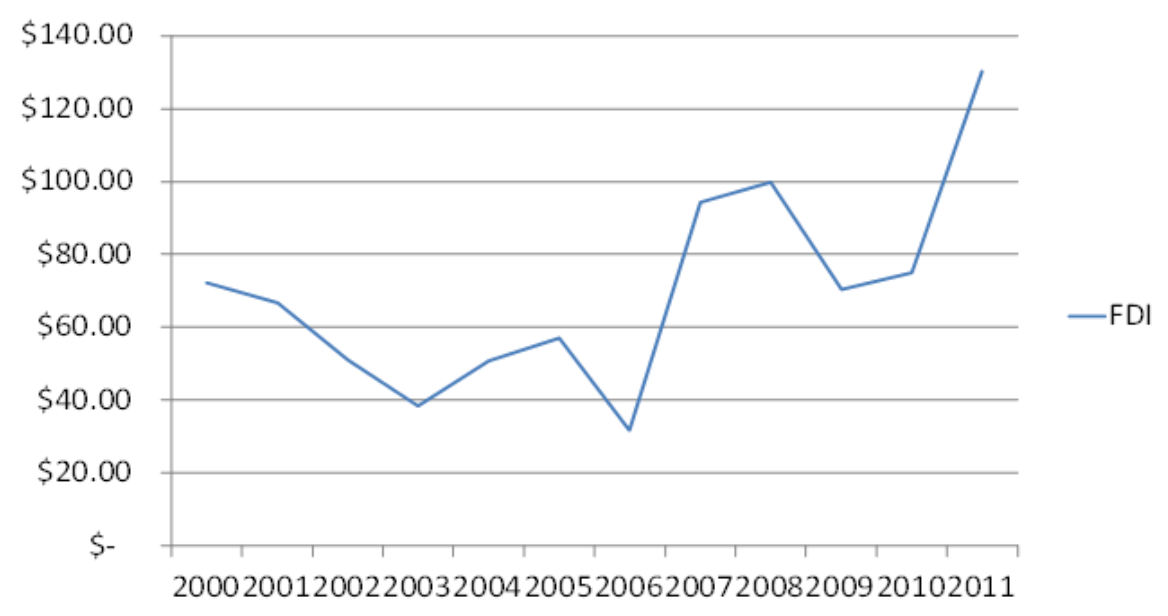

Fig. 1: FDI Flows to Latin America, 2000-2011 (Billions of dollars)

More importantly, from the standpoint of economic growth and development, the increase in FDI inflows has been driven by robust investments in Greenfield investments in manufacturing and services, particularly in South America (Brazil and Chile) and Mexico - in the latter it is primarily directed to the auto parts and assembly sector and manufacturing in general. According to UUNCTAD ([1]), gross investments in new enterprises in leading sectors of Latin America and the Caribbean rose from \$86.1 billion in 2005 to a high of \$144.3 billlion in 2008, before

falling to $\$ 120.1$ billion in 2010 and rebounding to 130.7 billion in 2011 ( [1]: Table .8, p. 191). In fact, as a result of the end of the privatization drive in most countries of the region, Greenfield investments have dwarfed those driven by cross border mergers and acquisitions. For example, total net sales in the region of existing enterprises to foreign concerns in the primary, manufacturing and services sector averaged only $\$ 15.5$ billion during the 2005-2011 period ([1]: Table I.3, p. 179). As indicated above, the relatively high rate of return on FDI investment in the region has also spurred FDI inflows, particularly to Argentina, Brazil, and Chile. UNCTAD (2 [1]) reports that the growth in income from FDI in South America rose "from an annual average of \$11 billion in 1994-2002, equivalent to 0.84 percent of the sub-region's GDP, to an annual average of $\$ 60$ billion during 2003-2011, equivalent to 2.44 percent of GDP. In 2011, FDI income increased another 17 percent, reaching \$95 billion" (p. 53).

In relative terms, Latin America=s share of FDI flows to developing countries rose from 29 percent in 1995 to an alltime high of 39.5 percent in 2000, before falling to 30.1 percent in 2003 and 28.6 percent in the recession year of 2009 , but rising once again to 32 percent in 2011 in the

wake of the strong surge in net FDI inflows, mainly confined to Argentina, Brazil, Chile, Colombia, Costa Rica, Mexico and Peru ([24]). As a proportion of their GDPs, the major countries (Argentina, Brazil, Chile, Colombia, Mexico, and Peru) of Latin America exhibited a consistently strong record of attracting FDI inflows during the decade of the 1990s, never falling below 1.5 percent of their countries= respective GDPs, and during the 2000s, FDI inflows averaged more than 3 percent in the case of Brazil, Chile, Costa Rica, Mexico and Peru (see [1]).

The importance of these inflows is better appreciated by focusing on their evolution relative to the gross fixed capital formation of the major countries of the region, given their role in financing private investment. Table 1 below shows that during the decade of the 1990s, and particularly after 1993, FDI inflows to the major countries of Latin America represented a significant percentage of their gross fixed capital formation; and in the case of Brazil, Colombia, Costa Rica, Chile, Ecuador, Peru, and Venezuela these flows reached at least one fifth of their gross fixed capital formation during the 1996-2001 period. For Latin America as a whole, Table 1 shows that FDI inflows as a proportion of gross capital formation rose impressively from an average of only 8.5 percent during the 1987-96 period to a high of 24 percent in 1999, before falling to 20 percent in 2001. Clearly, during the period in question, Latin America exhibited an impressive record of attracting FDI flows to finance gross fixed capital formation (see [25]: Table B.5, pp. 505-07). 
Notable performers during this period are Argentina, Chile, Costa Rica, Mexico, and Uruguay. However, as noted above, following the relatively mild U.S. recession of 2001 and the serious economic crisis in Argentina in 2001-2002, FDI inflows as a percentage of gross fixed capital formation fell sharply to a decennial low of 13 percent in 2003. However, Table 1 shows that after 2003 the share of FDI inflows rebounded sharply to 24 percent in 2008, [Table 1 approx. here] and despite the aftermath of the Great Recession of 2007-09, they have proven to be more resilient this time around and fallen only to approximately 19 percent in 2009-10.

Critics of the role of TNCs in Latin America (and elsewhere) are quick to point out that FDI inflows, even in the best of times, rather than increasing the investable resources of the host nation, actually divert resources away from capital formation because, after a few years, they generate substantial reverse flows in the form of remittances of profit and dividends to the parent companies. They also contend that the reported reverse flows are probably a gross underestimate because of the widespread practice of intra-firm transfer pricing by TNCs, i.e., under-voicing of subsidiaries' exports and over-invoicing of their imports of capital goods and technology (see [16]; [14]). In their view, in order to assess the net contribution of FDI to the financing of private capital formation, one must subtract from gross FDI inflows the repatriation of profits and dividends to the parent companies, often residing in the U.S. for many of the countries in question. Partial support for this contention can be surmised from the following figures: profit and dividend remittances by Latin America and the Caribbean to the developed countries more than doubled between 2004 and 2008 , from $\$ 33.6$ billion to $\$ 82.2$ billion (see [23]: Table 2.2.1.1, p. 97). ${ }^{2}$ To put these figures in perspective, in 2004 and 2008 , net FDI inflows to the region were respectively $\$ 50.8$ and $\$ 98.6$ billion; that is, reverse outflows in the form of profits and dividends from Latin America and the Caribbean to the developed countries grew from an already high 66 percent of net FDI inflows in 2004 to a sizable 83.4 percent in 2008! Moreover, from an individual country standpoint, the remittance of profits and dividends in recent years is even more alarming. For example, consider the case of Chile, a country that has been widely praised for its pursuit of market-based, outward-oriented policies and which has over the 2000-2010 period attracted vast amounts of net FDI inflows, particularly in view of its relatively small size. Nevertheless, given its highly liberal policies towards the repatriation of profits, it has also experienced a huge reverse flow of profits and dividends in recent years, rising from $\$ 2.5$ billion in 2000 to $\$ 11.4$ billion in 2005 and a whopping $\$ 19$ billion in 2010, far surpassing its gross inflows of FDI that year which stood at $\$ 15.4$ billion ([23])! In fact, Chile's remittances of profits and dividends during the 2000-2010 period far exceed those of Mexico's, a much larger country which received far more net FDI inflows over the same interval. ${ }^{i}$

In any event, the surge in FDI flows to the countries of Latin America during the 1990-2008 period was due, in part, to "push factors" in the industrialized countries such as relatively low rates of return on investments during the early 1990s (and early 2000s), as well as "pull factors" in Latin America such as the partial reduction of the debt burden via the use of ABrady bonds, expanding consumer markets and natural resource endowments, the implementation of credible macroeconomic stabilization policies, and market-based structural reform programs (see [26]; [1]). The latter include privatization and debt conversion programs, the liberalization of the tradable sector, the removal of overly restrictive FDI legislation concerning the repatriation of profits and prior authorization of investments, as well as eliminating sectoral restrictions such as local content and export requirements (see [27]; [1]).

The adoption of these outward-oriented, market-friendly policies has reassured both foreign and domestic investors in Latin America's commitment to market-based reforms in the medium run. Only time will tell if these reforms are sustainable in the long run from the standpoint of economic development, particularly in the wake of the U.S. recession of 2007-09, the economic and financial crises that have buffeted the region, particularly Argentina and Uruguay, and the emergence of China as a major destination for FDI flows (see [28]). ${ }^{3}$ In view of this, Latin America will have to redouble its efforts to attract FDI flows in a more selective manner so that it can modernize and develop its economy and reverse what has been until now a very disappointing regional investment and growth performance, particularly when compared to East Asia and China.

\section{Empirical model and results}

From an historical standpoint, empirical work on the determinants of FDI flows to Latin America and the Caribbean have been relatively few given the paucity and inconsistency of the data, as well as the economic and institutional heterogeneity present in these countries. However, in recent years, a number of studies focusing on the determinants (and impact) of FDI flows to several countries of the region have arisen as a result of the renewed surge in net flows to these countries beginning in the second half of the 1980s and the availability of reliable and methodologically consistent time series data for a number of countries (see [27]; [29]; [30]; [22]; [19]; [31];[17];[7]; and [32]]. 


\subsection{Model}

Following the lead of Agosin ([27], [21] and [7]), this study estimated a foreign direct investment (FDI) function that pools data for nine major Latin American nations: Argentina, Brazil, Chile, Colombia, Costa Rica, Ecuador, Mexico, Peru, and Uruguay over the 1980-2006 period. ${ }^{\text {ii }}$ The pooled (fixed-effects) model includes the effect of a number of relevant variables whose economic rationale for inclusion is discussed below. The simplest formulation of the pooled (stacked) regression model is given in Equation (1):

$(\text { FDIR })_{\text {it }}=f\left[(\operatorname{LGDP})_{\text {it-i }}, \operatorname{REX}_{\mathrm{it}-\mathrm{I}}, \mathrm{DS}_{\mathrm{it-i}, \mathrm{i}}, \mathrm{GIR}_{\mathrm{it}-\mathrm{i}}, \mathrm{GED}_{\mathrm{it}-\mathrm{i}}, \mathrm{CR}_{\mathrm{it}-\mathrm{i}}, \mathrm{EF}_{\mathrm{it}} ; \mathrm{D}_{\mathrm{i}}\right]+\varepsilon_{\mathrm{it}}$

where the regressand, FDIR, is the ratio of FDI inflows to real GDP; it includes standard regressors such as the (lagged) log of real GDP, the real exchange rate (REX) [as well as the period standard deviation (SDREX)], and the ratio of debt service payments to exports of goods and services (DS). It also incorporates public investment spending as a proportion of GDP (GIR), government expenditures on education as a percentage of GDP (GED) as a proxy for human capital, credit channeled by the banking system to the private sector (CR) as a percentage of GDP, the economic freedom index $(\mathrm{EF})$ generated by the Fraser Institute, and dummy variables $\left(\mathrm{D}_{\mathrm{i}}\right)$ to explain the variation in FDI flows to Latin America during the $1980-2006$ period. ${ }^{4} \varepsilon_{\mathrm{it}}$ is a normally distributed error term.

\subsection{Economic rationale}

Latin America's potential market size is proxied by the lagged value of the log of real GDP (LGDP) because foreign investors make their investment decisions based on expectations generated, in part, by what the level of real GDP was in the preceding year. The sign associated with this variable is expected to be positive. (The lagged growth rate of the $\log$ of real GDP was also included as an argument to determine whether it is the percentage change in log of real GDP that is the better proxy; see endnote 6 .) Although this variable was lagged, in part, to avoid the inherent simultaneity problem that arises when incorporating this variable as a regressor, viz., it is likely that increased FDI inflows enhance private capital formation and economic growth, this study also addressed the problem directly as follows: The potential endogeneity of the log of real GDP variable was purged by prior regression on FDI inflows. The residuals obtained from this regression were then renamed and substituted in place of the raw log of real GDP variable.

The real exchange rate is included in the model because it is the most important link between economic policy and international competitiveness and, as explained in Section II, it is expected to have an indeterminate sign in the Latin America case (see [27]). ${ }^{5}$ On the one hand, a considerable proportion of FDI flows to Latin America, in recent years, are concentrated in foreign affiliates which have a strong export orientation, such as agriculture, cellulose and paper, telecommunications, and manufacturing. A ceteris paribus real depreciation of the domestic currency (a rise in REX) should increase the profitability of these sectors and, ceteris paribus, induce FDI flows to them. On the other hand, a real depreciation of the domestic currency reduces the (dollar) value of the remittances of profits and dividends back to the parent company, thereby reducing the real rate of return on the parent company=s initial (dollar) investment. According to this rationale, a ceteris paribus depreciation of the domestic currency should reduce FDI flows to the country. This variable is introduced with a lag because the decision to invest in new plant, machinery, and equipment in a foreign country takes time due to recognition, implementation, and institutional-legal delays.

The standard deviation of the real exchange rate, $\operatorname{SD}(\mathrm{REX})$ was also included (separately) in the model to capture the impact of exchange rate volatility on FDI flows to the region. It is hypothesized that, ceteris paribus, this variable will have a negative effect on FDI flows to the regions because the more volatile REX is, the greater the uncertainty for foreign investors when it comes to the expected costs and profits in both the tradeable and non-tradeable sectors.

The debt service payments- to- exports ratio, was included to measure country risk; viz., the higher the ratio, the greater the probability that a BOP crisis will emerge which may lead to the imposition of restrictions on profit and dividend remittances, thereby depressing FDI flows to the country. Debt-service payments include both amortization (gradual payment of principal) and interest payments on the country's total external public debt. This variable is also designed to capture the influence of external (exogenous) factors on the Latin America economy, such as the increase in the cost of credit and/or demand for the country's exports. It is anticipated to have a negative and statistically significant effect on inward FDI flows.

Public investment as a proportion of GDP is included as regressor because it is hypothesized in the literature that, ceteris paribus, countries with better roads, bridges, and ports are, on average, more attractive to foreign investors as a result of lower production and transportation costs. However, the variable utilized in this study is not "clean" in the sense that it also includes investments undertaken by state-owned enterprises (SOEs) in key sectors of the economy such as industry, banking, mining, energy, and agriculture. If these investments are undertaken by heavily subsidized and/or inefficient SOEs, then government investment may directly (and indirectly via competition for scarce funds) "crowd out" both private domestic and foreign investment (see [33]). Moreover, during the period in question, many of the countries of Latin America pursued draconian IMF-sponsored stabilization and adjustment programs that led to 
unprecedented across-the-board cuts in public investment in economic and social infrastructure while, at the same time, they liberalized their economies to capital flows, including FDI flows. In view of this, although the sign of this variable is expected to be positive, it is also possible for it to have a negative correlation with FDI inflows.

The model also includes government expenditures on education as a percentage of GDP as crude proxy for the quality of the country's human capital. It would have been preferable to have used the secondary or tertiary enrollment ratio, but these variables were not available for the entire period for the countries in question. The rationale for including the GED variable is relatively straightforward. It is hypothesized that, ceteris paribus, the higher the level of education in any given country, the more attractive it is to foreign investors both from a cost standpoint (lower unit labor costs) and a demand-side perspective (greater purchasing power and more informed consumers) (see [19]). The credit variable (CR) is expected to have positive impact on FDI flows because, in many Latin American nations, the quantity constraint is binding in terms of financing the construction of new plant, machinery, and equipment. In other words, a greater pool of investible resources should, ceteris paribus, ease the financing constraint of both foreign and domestic investors (see [34]).

In order to assess whether the countries in question have a legal-institutional framework conducive to business activity, and are thus relatively more attractive to foreign (and domestic) investors, the well-known economic freedom index generated by the Fraser Institute was included in the model. The general idea is that countries with greater economic freedom have a legal-institutional framework that is more conducive to business activity and economic growth than countries that adopt policies that restrict economic freedom. This index is a summary measure of a number components of "economic freedom" such as monetary policy and price stability, the top marginal tax rate, legal structure and property rights, viability of contracts, and the rule of law. The index has a scale that ranges from 1 to 10, where a score of 10 represents the highest attainable level of economic freedom. ${ }^{6}$ It is anticipated that this variable will have a positive and statistically significant effect on inward FDI flows to the region. It should be noted that all of the countries in this study report indices that range between 2 and 8, with Chile and Costa Rica at the high end and Ecuador and Peru at the low end. Also, in view of the fact that Fraser Institute did not report economic freedom indices on a consistent basis for all of the countries in the sample, I generated the missing values via linear interpolation and linear extrapolation. The estimates reported in equation (5) in Table 2 below are for the 1980-2006 period.

Turning to the qualitative variables, dummy variable D1 equals 1 for the economic crises years associated with the onset and aftermath of the debt crisis (1982-84) and the negative spillover effects resulting from the Mexican Peso crisis of 1994-1995. It is expected to have a negative and significant effect on FDI flows to the region because of the uncertainty generated for expected returns from depressed economic activity and political turmoil. Again, these events may induce government officials to adopt a more nationalistic stance and impose restrictions on foreign investors in terms of the sectoral destination of FDI flows and the repatriation of profits and dividends. D2 is set equal to 1 for the 1991-94 period (acceleration of foreign investment flows to the region as a result of push factors in the developed nations and the implementation of market-based, outward-oriented strategies of economic growth and development that the major countries of the region began to implement following the Brady Plan. The model was also estimated with dummy variable D2 multiplied by real GDP. By estimating this variable interactively with real GDP one can assess whether the consolidation of market-oriented reforms had a positive and significant effect on the capacity of market size to affect real FDI flows.

\subsection{Data}

The data consists of 9 cross-sectional units, denoted $i=1, \ldots, 9$, observations at each of 27 periods, $t=1, \ldots, 27$, for a total of 243 observations. Most of the economic data (including foreign direct investment) used in this study were obtained from official sources such as various issues of ECLAC's Statistical Yearbook for Latin America and the Caribbean (Santiago: United Nations), UNCTAD's World Investment Report (Geneva: United Nations), and the World Bank Data (online). The data for public investment refers to fixed capital formation; i.e., it excludes financial investment. According to the International Finance Corporation (IFC), the data has been obtained from the following sources: World Bank Country Economic Memoranda, Public Investment Review, and Public Expenditure Reviews. For further details, see Everhart and Sumlinnski , I.F.C.'s Trends in Private Investment in Developing Countries: Statistics for 1970-2000 ([34]). Finally, the data for the economic freedom index was obtained from various Annual Reports of the Economic Freedom of the World published by The Fraser Institute.

\subsection{Results}

The estimated results for the various versions of the basic pooled model given in equation (1) above are displayed in Table 2. The pooled model was estimated via the Seemingly Unrelated Regression (SUR) procedure with white crosssection standard errors and covariances. The rationale for utilizing this procedure resides in the plausible hypothesis that economic events such as the debt crisis and/or the business cycle originating in the OECD countries are likely to affect 
FDI flows to all Latin American countries to varying degrees, thus generating cross-country correlations among the error terms. The generalized least square (GLS) method was used to correct all reported equations for the likely presence of first order serial correlation. Finally, all reported estimates were generated under the fixed effects assumption, viz., under the assumption that time-invariant differences across countries can be captured in differences in the constant term.

[Table 2 approx. here]

Equations (1)- (5) report fixed-effects (SUR) estimates for the basic model both with and without the dummy variables and, as can be readily ascertained, all estimates with the exception of the public investment variable have the anticipated sign and are statistically significant. For example, the lagged LGDP variable is highly significant in all specifications, suggesting that market size exercises a lagged positive effect on FDI flows to the region. ${ }^{7}$ The lagged credit variable (CR) is also positive and significant in all the reported estimations (with and without dummies), indicating that an easing of the credit constraint is an important determinant of FDI flows to the region. This is not an altogether surprising result in view of the fact that most of the credit granted by the banking sector in Latin America has traditionally been channeled to large enterprises, including subsidiaries of TNC's operating in key sectors of the countries in question (see [21]). As anticipated, the education variable has a positive and significant effect in all specifications. For example, the estimate in equation (1) suggests that a one percentage point increase in the current ratio of government expenditures on education to GDP will generate an increase of 0.3 percent in the share of FDI flows to the region during the following year, ceteris paribus.

The negative sign for the public investment variable suggests that increases in this variable, ceteris paribus, tend to crowd out FDI flows to the region for the period in question, but, as can be ascertained from the t-ratios in eqs. (1) - (4), it is not statistically significant. As noted above, this unanticipated result may be due to the fact that we are not able to isolate the effect of increased investment spending on economic infrastructure per se given the level of aggregation of the data. It may also be a "statistical artifact" generated from our inability to effectively control for the deleterious impact of the IMF-sponsored stabilization programs on public investment spending during the 1980s and 1990s in several of the countries included in this study.

Turning to the real exchange rate variable, it can be readily seen that it has a lagged positive effect on FDI flows, suggesting that a ceteris paribus real depreciation of the currency has enhanced the profitability of export-oriented sectors where FDI flows have been concentrated in recent years. Equations (2), (3), and (4) include the SDREX variable designed to capture the impact of the volatility of REX (uncertainty) on FDI flows to the region and, as expected, it has a negative and highly significant effect. The debt-service variable also has a lagged negative effect in all reported estimations, thus suggesting that increased country risk has a detrimental effect on FDI flows to the region [it should be noted that this variable also had a contemporaneous negative and significant effect].

As expected, the economic freedom variable (lagged one period) has a positive and highly significant effect in equation (5) for the period under review without altering the significance or sign of the other quantitative variables. The interpretation of this variable should be undertaken with care given its inherently subjective nature, but the estimate does suggest that a "better" macroeconomic environment and legal-institutional framework is conducive to attracting FDI flows to the region. The dummy variables reported in equations (3) and (5) also have their anticipated effects, and the interaction term reported in equation (4) suggests that the market-based, outward-oriented reforms of the early 1990s further enhanced the impact of market size on FDI flows to Latin America.

To determine whether the null hypothesis that there are no cross-correlations across countries (the homogeneity assumption) is valid, we utilized the following likelihood ratio test:

$\lambda \operatorname{lr}=-2(\ln L r-\ln L u)$

This test statistic is asympotically distributed as a chi-squared random variable with [n(n-1)]/2 (36) degrees of freedom, where $\mathrm{n}$ denotes the number of cross sections. LnLr refers to the log likelihood for the constrained model and the $1 \mathrm{nLu}$ is the log likelihood for the unconstrained (SUR) model. The critical values at the 1 and 5 percent level are, respectively 50.9 and 43.8. The computed likelihood ratio statistics reported in Table 2 (row $\lambda \mathrm{lr}$ ) are all significant at least at the 5 percent level. These estimates indicate that the null hypothesis of no cross-correlation across the nine countries can be rejected. That is, it is not possible for researchers to assume away the economic impact of regional shocks when estimating pooled investment functions for the region over the past two decades.

\subsection{Panel unit root tests}

A well established practice in individual time series work is to determine whether the individual variables are nonstationary (exhibit unit roots) and if they are related to one another in a stable long-run (cointegrated) relationship. In recent years, a number of investigators, notably Levin, Lin and Chu ([35]), Breitung ([36]), Hadri ([37]), Pedroni ([38]), and Im, Pesaran and Shin ([39]) have developed panel-based unit root tests that are similar to tests carried out on a single series. Interestingly, these investigators have shown that panel unit root tests are more powerful (less likely to 
commit a Type II error) than unit root tests applied to individual series because the time series dimension is enhanced by the number of cross sections (see [40]). Moreover, in contrast to individual unit root tests which have complicated limiting distributions, panel unit root tests have the added benefit that they lead to statistics with a normal distribution in the limit.

With the exception of the IPS, Pedroni, and the ADF Fisher Chi-Square tests, all of the aforementioned tests assume that there is a common (identical) unit root process across the relevant cross-sections. The LLC and Breitung tests employ a null hypothesis of a unit root using the following basic Augmented Dickey Fuller (ADF) specification:

$\Delta$ eit $=\alpha e i t-1+\Sigma \beta \mathrm{ij} \Delta \mathrm{eit}-\mathrm{j}+\mathrm{Xit} \delta+v i t$

where eit refers to the (stacked) residuals of the SUR regressions in Table 2, X' represents exogenous variables in the model such as country fixed effects and individual time trends, and vit refers to the error terms which are assumed to be mutually independent disturbances. 8 As indicated above, it is also assumed that $\alpha=\rho-1$ is identical across the nine cross-sections, but the lag order for the difference terms across the nine countries is allowed to vary. By contrast, the less restrictive IPS test (and ADF Fisher Chi-square test reported below) estimates a separate ADF regression for each of the nine cross sections to allow for individual unit root processes; i.e., $\rho$ i may vary across cross-sections which means that, under the alternative hypothesis, some (but not all) series can still be non-stationary.

Table 3 below reports (summary) panel unit root tests on the residuals of the five SUR regressions reported in Table 2 above. As can be readily seen, the LLC, Breitung and IPS tests strongly reject the unit root null for all of the equations reported in Table 2. The table also reports the widely used Hadri-Z test statistic, which, as opposed to the aforementioned tests, uses a null of no unit root. Again, the results of this test are consistent with those of LLC and Breitung because it fails to reject the null in favor of a unit root.

[Table 3 approx. here]

This study also performed an ADF Fisher unit root test proposed by Maddala and Wu ([41]) to determine whether the residuals of each of the nine cross-sections exhibit a unit root. In this test, the null hypothesis of a unit root for all nine cross sections is set against the alternative hypothesis of some [not all] cross sections without a unit root. The p-values reported in Table 4 for each cross section suggest that, with the exception of Ecuador, a unit root can be rejected at least at the 5 percent level. Also, the ADF Fisher statistic (83.561) and the Choi Z-stat. (-6.260) for the stacked residuals indicate that the null hypothesis of non-stationarity is strongly rejected.

The finding that the (stacked) residuals, including all but one of the residuals from the individual cross sections, do not contain a unit root suggests that there exists an equilibrium (stable) relationship that keeps the relevant variables in the pooled FDI function in proportion to one another in the long run. This is a highly important finding because often in panel studies researchers incorrectly apply the GLS method to regressions that are nonstationary in nature, thereby generating spurious results (see [40]).

[Table 4 approx. here]

Finally, the recently developed Residual Cointegration Test proposed by Pedroni ([38]) was employed. Basically, it generates four panel statistics and three group statistics to test the null hypothesis of no cointegration against the alternative of cointegration. In the case of panel statistics, the first-order autoregressive term is assumed to be the same across all the nine cross sections (the so-called within dimension test), while in the case of group statistics the parameter is allowed to vary over the cross sections (referred to as the between-dimension test). If the null is rejected in the more restrictive panel case, then the variables of the foreign investment function are cointegrated for all the countries. On the other hand, if the null is rejected in the group panel case, then cointegration among the relevant variables exists for at least one of the nine countries.

The statistics presented in Table 5 are distributed, in the limit, as standard normal variables with a left hand rejection region, with the exception of the variance ratio statistic. The reported panel and group statistics for the residuals generated from equation (5) suggest that there is strong evidence of cointegration. The reported statistics for the Augmented Dickey Fuller (ADF)-t and Phillips and Perron (non-parametric)-t tests suggest that the null hypothesis of no cointegration can be rejected at the five percent level of significance.

[Table 5 approx. here]

\section{Summary and conclusions}

To frame the important discussion regarding the determinants of FDI flows to Latin America, this paper began by outlining a number of hypotheses in the extant literature, with particular emphasis on Dunning's conceptual framework of analysis. Second, the evidence reported in Section II suggests that gross inward FDI flows to Latin America during the decade of the 1990s and 2000s have been substantial, both in relation to GDP and domestic capital formation. Another favorable trend in recent years is the high proportion of FDI flows directed to Greenfield investments, viz., in 
new enterprises in leading sectors, as opposed to cross-border mergers and acquisitions that were relatively more important during the privatization frenzy that hit the region during the 1990s. However, the evidence also indicates that reverse flows in the form of profit and dividend remittances--not to mention unreported transfers-have been equally strong, and once they are deducted from the gross FDI inflows, the contribution of FDI to the financing of capital formation, although increasing, is far less than advertised. From the standpoint of long-term economic development, this worrisome trend brings into question overly liberal short-run policies designed to attract FDI flows to the region, such as the elimination of taxes on repatriated profits and dividends and the phasing out of local content and export requirements.

Third, the SUR regressions suggest that market size (proxied by lagged real GDP or the lagged growth rate in real GDP) has a positive and statistically significant effect on FDI flows to the region. This result is in line with that of most studies which find that TNCs are most interested in the market potential of the host country. The lagged real exchange rate, the lagged credit variable, and the education variable also have a positive and significant effect on FDI flows, but, as anticipated, the debt-service ratio and standard deviation of the real exchange rate have a negative and statistically significant impact. The latter estimate suggests that increased uncertainty, as measured by the volatility of the real exchange rate, has a highly deleterious effect on FDI flows to the region. The institutional variables, as captured by the dummy variables and the Fraser Institute's economic freedom variable, have their anticipated effects, with the economic freedom variable having a positive and economically important effect on FDI flows. The only variable with an unanticipated (negative) sign is lagged public investment as a percentage of GDP-yet, it is not statistically significant in all the reported specifications. As explained in the text, this may be due to a number of factors, ranging from data problems which prevent us from isolating the effect of infrastructure investment spending per se to the unprecedented reduction in the ratio of public investment to GDP as a result of the implementation of severe stabilization and adjustment programs in several countries of the region for the period under review.

Fourth, this study performed panel unit root tests on the pooled residuals of the SUR regressions and determined that a non-spurious (cointegrated) relationship exists among the relevant variables. This is a highly important finding because it indicates that the variables of the pooled model have a stable long-term relationship that keeps them in proportion to one another.

From a policy standpoint, the results in this paper, which are consistent with those of other studies cited above, suggest that policies that promote sustained economic growth, investments in education, macroeconomic stability, particularly real exchange rate stability, and a legal-institutional framework conducive to business activity, are likely to attract FDI flows to the region on a long-term basis.

Table 1: Selected Latin American Nations: Foreign Direct Investment Flows as a Percentage of Gross Fixed Capital Formation, 1987-2010.

\begin{tabular}{lccccccccccccccccc}
\hline Country 1987-1996 & $\mathbf{1 9 9 7}$ & $\mathbf{1 9 9 8}$ & $\mathbf{1 9 9 9}$ & $\mathbf{2 0 0 0}$ & $\mathbf{2 0 0 1}$ & $\mathbf{2 0 0 2}$ & $\mathbf{2 0 0 3}$ & $\mathbf{2 0 0 4}$ & $\mathbf{2 0 0 5}$ & $\mathbf{2 0 0 6}$ & $\mathbf{2 0 0 7}$ & $\mathbf{2 0 0 8}$ & $\mathbf{2 0 0 9}$ & $\mathbf{2 0 1 0}$ \\
\hline Argentina & 8.5 & 2.7 & 8.4 & 28.5 & 25.3 & 8.4 & 17.6 & 9.6 & 15.0 & 11.0 & 11.1 & 10.1 & 11.8 & 5.9 & 7.7 \\
Brazil & 3.3 & 11.9 & 25.9 & 25.1 & 28.4 & 22.7 & 19.6 & 11.3 & 16.0 & 9.0 & 10.3 & 14.0 & 13.9 & 8.8 & 11.0 \\
Chile & 16.9 & 27.9 & 12.1 & 36.5 & 22.9 & 31.4 & 17.8 & 28.2 & 39.2 & 18.3 & 24.3 & 33.0 & 35.6 & 34.1 & 31.0 \\
Colombia & 10.8 & 38.2 & 19.4 & 14.4 & 21.1 & 21.8 & 17.6 & 16.1 & 17.1 & 18.0 & 18.8 & 18.7 & 17.6 & 12.2 & 10.0 \\
Costa Rica & 18.7 & 26.0 & 33.7 & 37.3 & 14.4 & 15.3 & 20.7 & 17.2 & 22.9 & 18.3 & 32.5 & 33.8 & 30.3 & 22.7 & 20.7 \\
Ecuador & 13.8 & 18.5 & 25.5 & 28.4 & 32.7 & 45.2 & 23.0 & 25.1 & 16.5 & 6.0 & 3.3 & 1.9 & 8.1 & 2.8 & 4.0 \\
Mexico & 13.9 & 16.3 & 15.8 & 15.3 & 13.7 & 20.7 & 12.1 & 9.4 & 16.7 & 8.0 & 10.0 & 13.9 & 11.0 & 8.8 & 9.3 \\
Peru & 15.6 & 11.1 & 14.2 & 16.9 & 6.8 & 11.6 & 21.6 & 12.3 & 12.8 & 18.3 & 18.6 & 22.3 & 19.5 & 25.9 & 18.1 \\
Uruguay & 6.3 & 5.3 & 8.9 & 13.9 & 10.3 & 14.0 & 15.6 & 39.4 & 22.3 & 39.0 & 41.1 & 29.9 & 32.6 & 25.4 & 28.9 \\
Venezuela & 7.5 & 34.4 & 29.3 & 23.3 & 25.9 & 16.7 & 3.8 & 20.4 & 7.7 & 5.0 & 2.1 & 2.6 & 1.5 & 1.3 & 2.1 \\
\hline $\begin{array}{l}\text { Latin } \\
\text { America }\end{array}$ & $\mathbf{8 . 5}$ & $\mathbf{1 6 . 1}$ & $\mathbf{1 9 . 3}$ & $\mathbf{2 4 . 0}$ & $\mathbf{2 0 . 7}$ & $\mathbf{2 0 . 0}$ & $\mathbf{1 5 . 4}$ & $\mathbf{1 3 . 0}$ & $\mathbf{2 4 . 1}$ & $\mathbf{1 5 . 1}$ & $\mathbf{1 5 . 6}$ & $\mathbf{2 0 . 8}$ & $\mathbf{2 3 . 5}$ & $\mathbf{1 8 . 9}$ & $\mathbf{1 9 . 6}$ \\
\hline
\end{tabular}

Source: Computed by author from UNCTAD, World Investment Report, 1999, Tables B.1. and B.5., pp. 478 and 505-507; UNCTAD, World Investment Report, 2012, Annex Table I.1, p.171; ECLAC, Economic Survey of Latin America and the Caribbean, 2012, Tables A2 and A6, pp. 119-20; and ECLAC, Statistical Annex, 2011, Table 2.1.1.5, p. 81, 
Table 2: Seemingly Unrelated Regression (SUR), Dependent variable: FDI $_{t}$.

\begin{tabular}{|c|c|c|c|c|c|}
\hline \multicolumn{6}{|c|}{ Regressions (1980-2006) } \\
\hline Variables & (1) & (2) & (3) & (4) & (5) \\
\hline $\operatorname{LGDP}_{\mathrm{t}-1}$ & $\begin{array}{c}2.94 \\
(3.94)^{* *}\end{array}$ & $\begin{array}{l}3.14 \\
(4.32) * *\end{array}$ & $\begin{array}{l}3.11 \\
(4.43)^{* *}\end{array}$ & $\begin{array}{l}2.88 \\
(4.07)^{* *}\end{array}$ & $\begin{array}{l}2.94 \\
(3.98) * *\end{array}$ \\
\hline $\mathrm{D}_{2} *(\mathrm{LGDP}$ & )$_{t-1} \quad----$ & ---- & ---- & $\begin{array}{c}0.04 \\
(2.82)^{* *}\end{array}$ & ---- \\
\hline $\mathrm{CR}_{\mathrm{t}-3}$ & $\begin{array}{c}0.03 \\
(4.85)^{* *}\end{array}$ & $\begin{array}{c}0.03 \\
(4.79)^{* *}\end{array}$ & $\begin{array}{l}0.03 \\
(4.96)^{* *}\end{array}$ & $\begin{array}{l}0.03 \\
(4.89)^{* *}\end{array}$ & $\begin{array}{l}0.03 \\
(5.76)^{* *}\end{array}$ \\
\hline $\mathrm{GIR}_{\mathrm{t}-1}$ & $\begin{array}{c}-0.11 \\
(-1.26)\end{array}$ & $\begin{array}{l}-0.10 \\
(-1.08)\end{array}$ & $\begin{array}{c}-0.10 \\
(-1.12)\end{array}$ & $\begin{array}{l}-0.09 \\
(-1.17)\end{array}$ & ---- \\
\hline $\mathrm{GED}_{\mathrm{t}-1}$ & $\begin{array}{c}0.27 \\
(2.24)^{* *}\end{array}$ & $\begin{array}{l}0.24 \\
(1.91)^{* *}\end{array}$ & $\begin{array}{l}0.27 \\
(2.20)^{* *}\end{array}$ & $\begin{array}{l}0.28 \\
(2.44)^{* *}\end{array}$ & $\begin{array}{c}0.27 \\
(2.19)^{* *}\end{array}$ \\
\hline $\mathrm{DS}_{\mathrm{t}-1}$ & $\begin{array}{c}-0.02 \\
(-2.51)^{* *}\end{array}$ & $\begin{array}{l}-0.02 \\
(-2.49)^{* *}\end{array}$ & $\begin{array}{c}-0.02 \\
(-2.23)^{* *}\end{array}$ & $\begin{array}{l}-0.02 \\
(-2.54)^{* *}\end{array}$ & $\begin{array}{l}-0.02 \\
(-2.37)^{* *}\end{array}$ \\
\hline $\mathrm{REX}_{\mathrm{t}-1}$ & $\begin{array}{c}0.06 \\
(1.80)^{* *}\end{array}$ & -- & - & ---- & $\begin{array}{l}0.05 \\
(1.54)^{*}\end{array}$ \\
\hline SDREX $_{\mathrm{t}-1}$ & - & $\begin{array}{l}-0.22 \\
(-1.71)^{* *}\end{array}$ & $\begin{array}{l}-0.14 \\
(-1.63)^{*}\end{array}$ & $\begin{array}{l}-0.24 \\
(-2.03)^{* *}\end{array}$ & ---- \\
\hline $\mathrm{EF}_{\mathrm{t}-1}$ & $\begin{array}{c}0.32 \\
(2.54)^{* *}\end{array}$ & $\begin{array}{l}0.29 \\
(2.61)^{* *}\end{array}$ & $\begin{array}{l}0.25 \\
(1.95)^{* *}\end{array}$ & --- & $\begin{array}{l}0.36 \\
(2.97)^{* *}\end{array}$ \\
\hline $\mathrm{D}_{1}$ & ---- & ---- & $\begin{array}{c}-0.64 \\
(-3.99)^{* *}\end{array}$ & ---- & $\begin{array}{c}-0.47 \\
(-2.57)^{* *}\end{array}$ \\
\hline $\mathrm{D}_{2}$ & ----- & ---- & $\begin{array}{c}0.43 \\
(3.12)^{* *}\end{array}$ & ---- & ---- \\
\hline $\operatorname{AdjR}^{2}$ & .75 & .76 & .80 & .76 & .77 \\
\hline$\lambda_{\mathrm{lr}}$ & $63.4 * *$ & $59.4 * *$ & $57.3 * *$ & $62.3 * *$ & $64.1 * *$ \\
\hline obs. & 216 & 216 & 216 & 216 & 216 \\
\hline D.W. & 2.00 & 1.99 & 2.00 & 1.99 & 2.00 \\
\hline
\end{tabular}

Table 3: Pool Unit Root Tests on Residuals: Individual Effects Estimation, 1980-2006.

\begin{tabular}{lccccc}
\hline \multicolumn{5}{c}{ Equations } \\
\hline Method & $(1)$ & $(2)$ & $(3)$ & $(4)$ & $(5)$ \\
\hline LLC & $-7.42^{*}$ & $-7.51^{*}$ & $-7.30^{*}$ & $-6.61^{*}$ & $-5.38^{*}$ \\
Breitung & $-4.33^{*}$ & $-2.31^{*}$ & $-3.39^{*}$ & $-2.54^{*}$ & $-2.94^{*}$ \\
IPS & $-7.28^{*}$ & $-8.05^{*}$ & $-7.93^{*}$ & $-7.23^{*}$ & $-6.51^{*}$ \\
Hadri & 1.31 & 1.13 & 1.15 & 0.99 & 1.71 \\
\hline
\end{tabular}

Note: LLC= Levin, Lin, Chu (2002), IPS= Im, Pesaran, Shin (2003). The statistics are asymptotically distributed as standard normal with a left hand side rejection area, except on the Hadri test, which is right sided. A $*$ indicates the rejection of the null hypothesis of nonstationarity (LLC, Breitung, IPS) or stationarity (Hadri) at least at the 5 percent level of significance. Estimations undertaken with Eviews7.2 
Table 4: ADF Fisher Unit Root Test on Residuals: Individual Effects Estimation, 1980-2006.

\begin{tabular}{|c|c|c|c|c|}
\hline Method & & Statistic & Prob & \\
\hline ADF Fisher Chi-square & & 83.561 & 0.000 & \\
\hline ADF Choi Z-stat & & -6.260 & 0.000 & \\
\hline \multicolumn{5}{|c|}{ Intermediate ADF Test Results on Residuals } \\
\hline Cross Section & Prob. & Lag & Max Lag & Obs. \\
\hline RESID AR & 0.0044 & 0 & 4 & 20 \\
\hline RESID BA & 0.0428 & 0 & 4 & 20 \\
\hline RESID CH & 0.0001 & 0 & 4 & 20 \\
\hline RESID CO & 0.0009 & 1 & 4 & 19 \\
\hline RESID CR & 0.4348 & 2 & 4 & 18 \\
\hline RESID EC & 0.0242 & 0 & 4 & 20 \\
\hline RESID ME & 0.0022 & 0 & 4 & 20 \\
\hline RESID PE & 0.0016 & 0 & 4 & 20 \\
\hline RESID UR & 0.1131 & 1 & 4 & 19 \\
\hline
\end{tabular}

Note: Probabilities for Fisher tests are computed using an asymptotic Chi-square distribution. Automatic selection of lags based on Schwartz Information Criterion: 0-4. Total number of observations: 176. Estimations performed by Eviews7.2.

Table 5: Pedroni Residual Cointegration Test, 1980-2006. Null Hypothesis: No cointegration

\begin{tabular}{lcc}
\hline & Alternate Hypothesis: common AR coefs. (within-dimension). \\
\hline & Statistic & Probability \\
\hline Panel rho-statistic & 2.018 & 0.567 \\
Panel PP-statistic & -2.688 & 0.003 \\
Panel ADF-statistic & -4.055 & 0.000 \\
\hline & Alternative Hypothesis: individual AR coefs. (between-dimension) \\
\hline & Statistic & Probability \\
\hline & 3.299 & 0.995 \\
Group rho-statistic & -5.704 & 0.000 \\
Group PP-statistic & -3.038 & 0.001 \\
\hline
\end{tabular}

Total number of observations: $243(27 * 9)$. Lag selection: SIC with a maximum lag of 3. Estimations performed by Eviews7.2

\section{References}

[1] UNCTAD, World Investment Report 2012, New York: United Nations Conference on Trade and Development, 2012.

[2] G. Bird, and R.S. Rajan, International Currency Taxation and Currency Stabilization Developing Countries, The Journal of Development Studies 37 (2001): 21-38.

[3] Bosworth, B. P. and Collins, S.M. (1999). Capital Flows to Developing Economies: Implications for Savings and Investment, Brookings Papers on Economic Activity, No.1, 143-80.

[4] A, Kumar, Does Foreign Direct Investment Help Emerging Economies? Economic Letter 2 (2007): 1-8.

[5] J.A. Montecinos, and J. A. Cordero, Capital Controls and Monetary Policy in Developing Countries, Center for Economic and Policy Research, Washington, D.C., (April 2010): 1-33. 
[6] E.S. Prasan and R.G. Rajan, A Pragmatic Approach to Capital Account Liberalization, 22 (2008): 149-172.

[7] K. H. Zhang, Does FDI Promote Economic Growth? Evidence from East Asia and Latin America, Contemporary Economic Policy 19 (2001): $175-185$.

[8] M. Wang and M.C.S. Wong, What Drives Economic Growth? The Case of Cross-Border M\&A and Greenfield FDI Activities, Kyklos 62 (2009): 316-330.

[9] J. H. Dunning, J. H., International Production and the Multinational Enterprise, Allen \& Unwin, Publishers, USA, 1981.

[10] J. H. Dunning, J. H., Explaining International Production, London: Harper \& Collins, 1988.

[11] M. Mortimore, The Impact of TNC Strategies on Development in Latin America and the Caribbean, Published for Overseas Development Institute (UK), (2003): 1-23.

[12] J.R. Markusen, Incorporating the Multinational Enterprise into the Theory of International Trade, Journal of Economic Perspectives 9 (1995): 169-189.

[13] R. Aliber, A Theory of Direct Foreign Investment, in C.P. Kindleberger. C.P., ed., The International Corporation: A Symposium. Cambridge, MA: MIT Press, 1970 .

[14] J. M. Cypher, and J. L. Dietz, The Process of Economic Development, Routledge, USA, 2004.

[15] M.D. Levi, International Finance, 4th ed., Routledge, USA, 2005.

[16] H. J. Chang, Bad Samaritans, Bloomsbury Press, USA, 2008.

[17] R. Ram and K.H. Zhang, Foreign Direct Investment and Economic Growth: Evidence from Cross-Country Data for the 1990s, Economic Development and Cultural Change 51 (2002): 205-215.

[18] T.J. Yeager, Institutions, Transition Economies, and Economic Development, Westview Press, USA, 1999.

[19] B. Ramasamy and M. Yeung, The European Union's Foreign Direct Investment into Indonesia: Determinants and Threats, in H.S. Kehal, Foreign Direct Investment in Developing Countries, Palgrave Macmillan, Ltd., USA, 2004.

[20] D.C. North, Institutions, Institutional Change and Economic Performance, Cambridge University Press, USA, 1990.

[21] ECLAC, La Inversion Extranjera en America Latina y El Caribe, Santiago, Chile: United Nations, 1998.

[22] L.R. De Mello, Jr., Foreign Direct Investment in Developing Countries and Growth: A Selective Survey, Journal of Development Studies 34 (1997): 1-34.

[23] ECLAC, Economic Survey of Latin America and the Caribbean 2010-2011, Santiago, Chile: United Nations, 2012.

[24] UNCTAD, World Investment Report 2007, New York: United Nations Conference on Trade and Development, 2007.

[25] UNCTAD, World Investment Report 1999, New York: United Nations Conference on Trade and Development, 1999.

[26] D. Green, Silent Revolution, New York, Monthly Review Press, 2003.

[27] M.R. Agosin, Foreign Direct Investment in Latin America, Inter-American Development Bank, USA, 1995.

[28] J.E. Stiglitz, J. E. (2003). Whither Reform? Towards a New Agenda for Latin America, Cepal Review 80 (2003): 7-38.

[29] M. Bloomstrom, and E.Wolff, Multinational Corporations and Productivity Convergence in Mexico, in W. Baumol, R. Nelson, and E. Wolff, eds., Convergence of Productivity: Cross-National Studies and Historical Evidence. Oxford: Oxford University Press, 1994.

[30] A. Chowdhury, and G. Mavrotas, FDI and Growth: What Causes What? World Economy 29 (2006): 9-19.

[31] M.D. Ramirez, Did Institutional Factors Enhance FDI Flows to Chile During the 1985-2001 Period? A Cointegration Analysis, Journal of Emerging Markets 10 (2005): 18-29.

[32] K. Vadlamannati, and A. Tamazian, Growth Effects of Foreign Direct Investment and Economic Policy Reforms in Latin America, MPRA Paper No. 14133, 2009.

[33] S. Devarajan and H. Zou, Does Public Investment Promote Economic Growth? Working Paper No. 95-9, The Hong Kong University of Science and Technology (1994): 1-27.

[34] S.S. Everhart, and M.A. Sumlinski, Trends in Private Investment in Developing Countries: Statistics for 1970-2000, International Finance Corporation, 44, The World Bank, USA, 2001.

[35] Levin, A., Lin, C.F., and Chu, C. (2002). Unit Root Tests in Panel Data: Asymptotic and Finite-Sample Properties, Journal of Econometrics, $108,1-24$.

[36] J. Breitung, The Local Power of Some Unit Root Tests for Panel Data, in B. Baltagi, ed., Advances in Econometrics, Vol. 15: Non-stationary Panels, Panel Cointegration, and Dynamic Panels. Amsterdam: JAI Press, 2000.

[37] K. Hadri, K., Testing the Null Hypothesis of Stationarity Against the Alternative of a Unit Root in Panel Data with Serially Correlated Errors, Manuscript, Department of Economics and Accounting, University of Liverpool, 1999.

[38] P. Pedroni, Critical Values for Cointegration Tests in Heterogeneous Panels with Multiple Regressors, Working Paper, Indiana University (1999): 1-19. Subsequently published in Oxford Bulletin of Economics and Statistics, 61, Special Issue.

[39] K.S. Im, M.H. Pesaran, and Y. Shin, Testing for Unit Roots in Heterogeneous Panels, Journal of Econometrics 115 (2003): $53-74$.

[40] B. H. Baltagi, Econometric Analysis of Panel Data, 2nd ed., John Wiley \& Sons, LTD., USA, 2001.

[41] G.S. Maddala, and S.Wu,. A Comparative Study of Unit Root Tests with Panel Data and A New Simple Test, Oxford Bulletin of Economics and Statistics 61 (1999): 631-52.

1. Between 1990 and 2000, FDI inward stock in Latin America (1990 dollars) almost tripled (2.93 times)from $\$ 175.6$ billion to $\$ 507.4$ billion. More recent data reported by UNCTAD indicates that the surge has continued into the 2000s, with the stock of FDI quadrupling to $\$ 2.048 .1$ billion in 2011! (see [1], Table I.2, p. 175). In relative terms, FDI stock as a percentage of GDP rose from 10.1 percent in 1990 to 25 percent in 2001 [see [24]: Table B.3.) The remarkable increase in FDI inward stock during the 1990s is far greater than that of the entire "lost decade" of the 1980s. By comparison, China's FDI inward stock (1990 dollars) was less than half of Latin America's at an estimated \$193.4 billion in 2001, and although it rose sharply to an estimated $\$ 245.5$ billion in 2004, it was still far below that of Latin America which stood at an impressive $\$ 723.8$ billion [[24]: Table B.2].

2. The World Bank reports that profit remittances on FDI for Mexico averaged $\$ 6.9$ billion for the 2000-2010 period, while those for Chile averaged $\$ 11.3$ billion, or more than one and a half times as much. In fact, there were several years (2006-2008, and 2010) when profit remittances on FDI for Chile approximated or exceeded $\$ 20$ billion, while in 
the case of Mexico, there were three years (2006-2008) when they came close to $\$ 10$ billion. Needless to say, these flows are not only large in absolute terms but relative to GDP and GFCF as well.

3. Data for 2005 suggest that FDI inflows to China are estimated at US\$72.4 billion which, if confirmed, would fall slightly below the total inflows to Latin America and the Caribbean as a whole at an estimated US\$75.5 billion. In fact, China $=\mathrm{s}$ share of total worldwide FDI flows in 2005 was estimated at 7.7 percent, which would mean that China was the third largest recipient of FDI in the World, behind the United States and the United Kingdom (see [24], 2007).

4. Data for the variables in question were obtained from various issues of ECLAC and the World Data Bank (World Development Indicators). The period had to be shortened because several years of data were missing for variables such as public investment spending as a percentage of GDP, public spending on education as a percentage of GDP, and credit provided by the banking sector to private sector as a percentage of GDP.

5. See Agosin ([27]: 121-122) who reports estimates for a simple regression model that tries to explain the variation in FDI flows to Chile during the 1975-93 period. He finds that both the level of real GDP in constant dollars and the real depreciation of the exchange have a positive and statistically significant effect on FDI flows. He also includes a dummy variable to capture the adoption of the debt conversion program (Chapter XIX), and finds that it also has a positive and statistically significant impact on FDI flows. The major problem with this otherwise interesting paper is that the author does not undertake a cointegration analysis of the FDI investment relationship. Given the likely presence of unit roots in the data, the reported estimates are not reliable.

6. It would be preferable to use a more direct measure of costs such as unitary labor costs. Unfortunately, data on unit labor costs for the period under review is not available for all the countries in the sample in a consistent and reliable form.

7. It is important not to confuse economic freedom with political and civil liberties. Countries may confer upon their citizens a substantial amount of political and civil liberty in the form of fair and competitive elections and freedom of the press, but still pursue policies that are inimical to economic freedom such as high levels of taxation and excessive government intervention and regulation.

8. The regressions with the unpurged $\log$ of real GDP variable were similar to those reported in Table 2, but the magnitude of the estimated coefficients for the "raw" LGDP variables were significantly higher. The model was also estimated with the lagged growth rate in real GDP and the estimates are reported below:

$$
\begin{aligned}
& (\mathrm{FDI})_{\mathrm{t}}=\quad-0.72+0.02(\Delta \mathrm{LGDP})_{\mathrm{t}-1}+0.02(\mathrm{CR})_{\mathrm{t}-1}-0.20(\mathrm{GIR})_{\mathrm{t}-1}+0.24(\mathrm{GED})_{\mathrm{t}-1} \\
& \text { t-ratios: }(-1.10) \quad\left(\begin{array}{llll}
1.92) & (3.80) & (-4.57) & \text { (3.19) }
\end{array}\right. \\
& -0.03(D S)_{t}+0.11(\operatorname{REX})_{t-1}+0.58(\mathrm{EF})_{t-1} \\
& (-4.35) \quad(6.00) \quad(6.11) \\
& \text { Adj R2 }=0.87, \text { D.W. }=2.04, F \text { stat }=66.49
\end{aligned}
$$

As can be readily seen, the one-period lag growth rate is highly significant and its inclusion does not alter the significance nor the sign of the other variables. The lag structure was determined via the Akaike- Schwartz information criteria.

9. The rationale for testing whether the residuals of the SUR regressions exhibit a unit root stems from the finding that panel unit root tests on the included variables (available upon request) revealed that the credit and LGDP variables exhibited a unit root (non-stationarity) in level form. 